Agnieszka Lis-Czapiga

DOI $10.15290 / \mathrm{sw} .2017 .17 .05$

Uniwersytet Rzeszowski

Wydział Filologiczny

Katedra Filologii Rosyjskiej

tel. +48 178721220

e-mail: lis.agnieszka@interia.pl

\title{
Obraz miasta w poezji Władimira Korwin-Piotrowskiego
}

Słowa kluczowe: poezja rosyjska, pierwsza fala emigracji, Władimir Korwin-Piotrowski, miasto, ekspresjonizm

Władimir Korwin-Piotrowski (1891-1966) to poeta, dramaturg, prozaik, autor utworów dla dzieci [Kodzis, Wieczorek 1994, 140-141; Kasack 1996, 296-297; Скатов 1998, 654-657; Крейд 1999, 126-128], reprezentant młodszego pokolenia pierwszej fali emigracji rosyjskiej [Иванова 1998]1․ Z Rosji wyjechał w latach dwudziestych. Po przyjeździe do Niemiec (do Berlina) od razu zaangażował się w życie literackie diaspory, stając się jednym z jej znaczaccych działaczy. Nie tylko publikował utwory (na razie pod nazwiskiem Piotrowski), ale był, między innymi, redaktorem wydawnictwa „Manfred”, kierował działem poezji w czasopiśmie „Społochi” (1921-1923), należał do stowarzyszenia pisarzy „Wierietieno” (1922) i uczestniczył w wydaniu jego almanachu o tym samym tytule, był także jednym z wybitnych członków ugrupowania „Krużok poetow”, działającego od 1928 do 1933 roku. To tylko niektóre fakty z berlińskiego okresu literackiej działalności poety [Венцлова 2012, 405-409; Каннак 2003, 279-280].

W Niemczech Piotrowski wydał dwa zbiorki poezji Piolun i gwiazdy (Польнь и звезды, 1923), Kaтіеппа тіłоść (Каменная любовь, 1924),

1 Zob. też artykuł autora [Lis-Czapiga 2015]. 
zbiór opowiadań o zabarwieniu erotycznym Przypadki pana opata (Примеры господина аббата, 1923) i wiersze dla dzieci. Tomiki poetyckie, a tym bardziej proza nie należały do zbyt udanych, były raczej słabe. Poeta, dość krytycznie podchodzący do swojej twórczości, „wyrzekł się” wielu wierszy, a te najbardziej wartościowe przerobił. Pod koniec lat dwudziestych wydał zbiorek poematów dramatycznych Beatrycze (Беатpuчe, 1929), pozytywnie przyjęty w Berlinie [Струве 1996, 123; Kasack 1996, 269].

Jeszcze przed rozpoczęciem wojny w 1939 r. Piotrowski wyjechał do Paryża, gdzie uczestniczył w Ruchu Oporu; w 1944 został aresztowany. W gestapowskim więzieniu spędził dziesięć miesięcy; skazany na karę śmierci uniknął wyroku. Po wojnie uległ patriotycznym nastrojom panującym wśród emigracji rosyjskiej, rozważał nawet powrót do Związku Radzieckiego, jednak nigdy się na to nie zdecydował [Струве 1996, 123].

Talent poetycki Piotrowskiego w pełni ujawnił się po drugiej wojnie światowej. Od tej pory poeta wydawał swoje utwory już pod nazwiskiem Korwin-Piotrowski, co miało symbolizować jego odcięcie się od tych powstałych przed 1945 r. i wskazywać na zupełnie inny, nowy charakter twórczości [Скатов 1998, 656].

W powojennym Paryżu poeta włączył się w życie emigracji, publikował, uczestniczył w wieczorach i w nieformalnych kółkach literackich. Wydał tom poezji Latawiec (Воздушный змей, 1950), dobrze przyjęty przez krytykę, obejmujący wiersze od końca lat trzydziestych do końca czterdziestych (w tym też utwory powstałe i zapamiętane w więzieniu) oraz zbiór poematów i liryków Klęska (Поражение, 1960) poświęconych Rosji; od 1953 r. współpracował również z czasopismem „Nowyj Żurnal”. W 1961 poeta wraz z rodziną przeniósł się do Stanów Zjednoczonych, do Kalifornii i przyjął obywatelstwo amerykańskie [Kodzis, Wieczorek 1994, 140; Венцлова 2012, 416-418].

Po śmierci Korwin-Piotrowskiego w Waszyngtonie ukazało się 2-tomowe wydanie jego poezji i dramatów Późny gość (Поздний гость, 1968-1969, pod red. T. Fiesenko), które zaczął przygotowywać jeszcze sam autor. W 2012 r. w Moskwie wyszedł drukiem tom Późny gość. Wiersze i poematy (Поздний гость. Стихотворения и поэмь, pod red. T. Venclovy). Zbiór jest pierwszym, w miarę pełnym wydaniem utworów poety, jakie wyszło w Rosji², zawierającym zarówno utwory z amerykańskiego wydania, jak również wiersze napisane w Berlinie, juwenilia i utwory dotychczas niepublikowane [Венцлова 2012, 402, 422].

2 Pojedyncze utwory poetyckie i dramatyczne W. Korwin-Piotrowskiego w Rosji były publikowane po $1990 \mathrm{r}$. 
Korwin-Piotrowski tworzył $\mathrm{w}$ duchu ukształtowanych już tradycji literackich, w swojej liryce wchodził z nimi w swoisty dialog, rezygnował z typowych dla awangardy eksperymentów formalnych na rzecz prostoty stylu, precyzyjnego języka, niewyszukanego metrum (preferował czterostopowy jamb) oraz różnorodności form rytmicznych i dbałości o warstwę dźwiękową utworu [Скатов 1998, 656; Венцлова 2012, 402, 410, 427; Lis-Czapiga 2015]. Jak zauważa Tomas Venclova, twórczość Korwin-Piotrowskiego wpisuje się w ramy postsymbolizmu [Венцлова 2012, 402].

W pierwszym tomiku wierszy poety Piotun $i$ gwiazdy widoczny jest wpływ twórczości Siergieja Jesienina i imażynistów, z kolei w późnych utworach okresu berlińskiego i tych napisanych już w Paryżu Korwin-Piotrowski nawiązuje do Aleksandra Puszkina, poezji filozoficznej Jewgienija Baratynskiego, Fiodora Tiutczewa, w jego wierszach można odnotować również wpływ tradycji Michaiła Lermontowa, a także odwołania do twórczości Williama Szekspira [Венцлова 2012, 402, 410, 416-417]. Jak pisze Gleb Struwe, Korwin-Piotrowski wiele nauczył się od Władysława Chodasiewicza, w jego utworach są też reminiscencje Andrieja Biełego i Osipa Mandelsztama, ale jest on przede wszystkim poetą oryginalnym [Струве 1996, 242] $]^{3}$.

Do typowych cech poetyki autora, wskazywanych przez badaczy, należą, między innymi: osobliwość obrazów, oscylowanie na granicy realności i irrealności, a także naturalizmu i patetyczności. W liryce Korwin-Piotrowski odwołuje się do historycznej przeszłości (rzadziej do współczesności), do utworów wprowadza zdarzenia wojenne i ich opisy, obrazy kosmiczne, porusza też problem dwoistości świata [Струве 1996, 242; Kasack 1996, 269; Венцлова 2012, 410, 416-417]. Wiersze poety nabierają wymiaru metafizycznego, zyskuja ponadczasowy i uniwersalny charakter.

Spośród całego repertuaru tematów i motywów w poezji Korwin-Piotrowskiego na uwage zasługują utwory poświęcone obrazowi miasta. Tematyka ta niejednokrotnie staje się przedmiotem refleksji poetyckiej autora i zajmuje ważne miejsce $\mathrm{w}$ jego twórczości. Niewątpliwie w wierszach poety dotyczących metropolii można upatrywać wpływ nie tylko poezji rosyjskiej, ale także ekspresjonizmu niemieckiego [Венцлова 2012, 410]. Do poetyki prądu nawiązuje już sam wybór motywu tematycznego (ulubionego przez jego przedstawicieli i najczęściej spotykanego w ich twórczości [Nawrocki

3 Po przyjeździe do Paryża twórczość Korwin-Piotrowskiego została dość chłodno przyjęta w kręgach emigracji rosyjskiej, zresztą pod względem charakteru uprawianej twórczości trudno było zaliczyć go do paryskich grup poetyckich [„,nuty paryskiej”, „neoklasycystów”] [Терапиано 1987, 133, 237]. Poeta wprawdzie związał się z „formistami” (z Anną Prismanową, Aleksandrem Gingerem), jednak, jak zauważa T. Venclova, jego utwory nie miały zbyt wiele wspólnego z poetyką grupy [Венцлова 2012, 412]. 
1987, 10; Paszkiewicz 1999, 38; Kotkiewicz 2000, 29] oraz sposób kreacji obrazu miasta.

Poeta koncentruje się na wybranych aspektach miejskiej codzienności, obrazuje kadry z życia metropolii, eksponuje elementy pejzażu miejskiego, nierzadko posługując się przy tym konwencją groteski [Венцлова 2012, 410], tak typową dla ekspresjonizmu [Kotkiewicz 2000, 31-43]. Popularnym motywem poezji awangardowej jest też motyw drogi, wędrówki [Kotkiewicz 2000, 31-43; Ratajczak 2006, 124]. Stąd podmiot liryczny wierszy Korwin-Piotrowskiego lub ich bohaterowie nieraz wędrują ulicami miasta, są obserwatorami, a także świadkami wielu zdarzeń, zarówno tych zwyczajnych, jak również nierzeczywistych. Poeta wprowadza do utworów motywy przestępstwa, postaci z marginesu społecznego (przestępców, prostytutki), opisuje podejrzane i niebezpieczne miejsca, podrzędne restauracje i pogrążony w chaosie cywilizacyjnym świat, co można też odczytać jako odniesienie do estetyki symbolizmu, zwłaszcza poezji urbanistycznej Walerija Briusowa czy Aleksandra Błoka.

W wierszu Cienie pod mostem (Тени под мостом, 1928) na tle miejskiego zgiełku i brudu, pod jednym z mostów, przedstawia grających w karty hazardzistów - groźnego i bezwzględnego zabójcę oraz sprytnego złodzieja. Amorficzne postaci jawią się jedynie jako cienie, co pogłębia efekt odrealnienia rzeczywistości [Brzoza 1980, 127; Kotkiewicz 2000, 34-35]:

Где ночи нет, а день не нужен,

Под аркой гулкого моста

Азартом заменяя ужин,

Они играют в три листа.

На свалке городского хлама,

В лоскутьях краденых мешков [...]

[Корвин-Пиотровский 2012, 70]

Prowadzona przez nich gra staje się coraz bardziej dynamiczna (co podkreśla zastosowany w utworze asyndeton), ale też niebezpieczna i ryzykowna, gdyż stawką w niej okazują się być nie tylko pieniądze, ale przy próbie najmniejszego oszustwa również życie.

Jednak zaistniała sytuacja nie wywołuje lęku graczy. Podmiot liryczny konstatuje z ironią:

[...] Так, забавляясь и играя,

Подобные летучей мгле,

Легко любя и умирая,

Они проходят по земле. [...]

[Корвин-Пиотровский 2012, 70] 
Przestępcom obce są bowiem zmartwienia i kłopoty dnia codziennego, trud i wysiłek, traktują życie jako beztroską grę i zabawę, lekko i niepostrzeżenie przechodzą przez nie, a świadomość jego utraty nie przeraża. Bohaterowie mogą wzbudzać trwogę obserwatora lub przechodnia, ale nie są oni niebezpieczni. W pełni wyzwoleni, nieposiadający dóbr materialnych, pozostający poza wszelkimi ograniczeniami mają możliwość uczestniczenia we wszystkim, co jest dostępne dla innych jedynie we śnie:

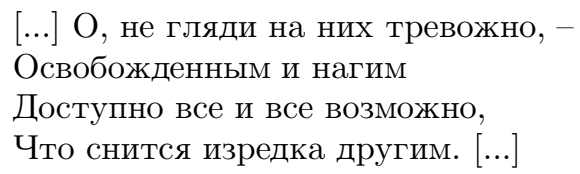

[Корвин-Пиотровский 2012, 70]

Do środowiska przestępczego nawiązują także wiersze $\mathrm{Na}$ ulicy $i$ mrok i mgła... (На уличе и мрак и мгла...) і Nad fantazyjnymi drzwiami lampa... (Над дверью вычурной фонарь..., 1955). W pierwszym pojawia się motyw bójki, rozlewu krwi, prostytutki, z kolei w drugim autor ukazuje starą miejską ulicę, zadymiony i duszny od swędu spalenizny lokal oraz potykającego się staruszka, recytującego przechodniom niemądry, pozbawiony sensu, niedorzeczny utwór. Ów domorosły uliczny poeta to schorowany i brudny lump, łotrzyk, bywalec obskurnych barów, uczestnik bijatyk, popadający w konflikt z prawem. Z tym ponurym obrazem ulicy kontrastuje smuga czystego światła padającego na jezdnię.

Miasto z utworów Korwin-Piotrowskiego żyje własnym życiem, przypomina żywy organizm, czego potwierdzeniem jest występująca w wielu wierszach animizacja („Над дверью вычурной фонарь // Сворачивает в ветер шею”; "Старинной улицы мечта // Румянцем новым подогрета” - Nad fantazyjnymi drzwiami lampa...; „прожектор в выси черной // Свой узкий распускает хвост" - Kiedy reflektor $w$ czarnych przestworzach..., Когда прожектор в вили черной..., 1928-1952; „Фонарь, зевая, // Оберегает черный мост" - Noc gtucha..., Глухая ночь..., 1929).

W miejskiej codzienności, zwyczajnej i zdawałoby się niczym niewyróżniającej, podmiot liryczny dostrzega również obecność sił tajemniczych, metafizycznych oraz pierwiastków irrealnych, demonicznych, zagrażających mu. Zanika granica pomiędzy realnością i dziwnością, pomiędzy snem a jawą [por.: Kotkiewicz 2000, 31, 33]. We wspomnianym już utworze Na ulicy i mrok $i$ mgla... czytamy: 
О, бедный мир, о, тихий ад,

Приют полуночного беса. [...]

[Корвин-Пиотровский 2012, 184]

Człowiek niekiedy doświadcza ich namacalnego istnienia i bliskości, co ilustruje wiersz Pudel (Пудель). Bohaterowi lirycznemu przesiadującemu $\mathrm{w}$ przepełnionej papierosowym dymem podrzędnej restauracji, niespodziewanie ukazuje się niezwykła wizja, podobna do sennej mary - hałas i gwar nagle milkną, całe pomieszczenie wraz z obecnymi w nim pogrąża się we mgle, z daleka dochodzą tylko przytłumione dźwięki, gdzieś na statku pośród burzowej ciemności zapłonął ogien, a on widzi tylko zarysy widmowej postaci - czarny łuk brwiowy, ostrą skron, słyszy nierówne kroki i skrzypienie. I chociaż to przywidzenie senne, czy raczej alkoholowe majaczenie, trwało tylko przez mgnienie, bohater otrząsa się, z uwagą obserwuje otoczenie, jednak niczego nie zauważa. Jedynie w winie daje się wyczuć zapach spalonej siarki, zaś nieopodal dostrzega mężczyznę, głaszczącego czarnego pudla, który z głuchym ujadaniem wyrywa się ku niemu.

Występująca w utworach mgła (Na ulicy i mrok i mgła..., Pudel), symbolizująca to, co nieokreślone, fantastyczne, znajdujące się na pograniczu rzeczywistości i nierzeczywistości, łącząca się z istotami demonicznymi [por.: Biedermann 2003, 215], a także martwe lustra (Pudel) - („неживые зеркала") - bez odbicia (w tradycji kulturowej zwiastun nieszczęścia) [por.: Biedermann 2003, 200] sygnalizują istnienie w świecie sił ciemności. O ich obecności jeszcze dobitniej świadczy zapach siarki, wyczuwany przez bohatera lirycznego, a zwłaszcza postać czarnego pudla (Pudel) - atrybuty sfery infernalnej. Pies z wiersza Korwin-Piotrowskiego jest niewątpliwie nawiązaniem do Fausta Johanna Wolfganga Goethego, w którym czarny pudel jest jednym z wcieleń Mefistofelesa [por.: Корвин-Пиотровский 2012, 432], z kolei doświadczenie bliskości sił tajemniczych, irrealnych, obraz pospolitego szynku i motyw cierpkiego wina wydaje się być odniesieniem do wiersza Nieznajoma (Незнакомка, 1906) Vłoka. Obrazowość wypowiedzi poetyckiej (Pudel) została dodatkowo wzmocniona poprzez użyty w utworze polisyndeton, który spowalnia intonację i podkreśla rozwój przedstawionego zjawiska, zaś zaimki nieokreślone (кто-то, чей-то) - jego niewytłumaczalny charakter.

Pokrewnej tematyce poświęcony jest także wiersz Kiedy wraca z praсу... (Когда с работы он идет..., 1937). Poeta rysuje w nim obraz na pozór niczym niewyróżniającego się, przeciętnego człowieka, wracającego z pracy po męczącym dniu, który po drodze zatrzymuje się w ubogiej karczmie. Jednak bohater utworu nie jest zwykłym śmiertelnikiem. Poprzecina- 
ne zmarszczkami czoło, noszące ślady burzliwych myśli, i niewyraźny ślad skrzydła zdradzają upadłego z nieba anioła, księcia ciemności:

\author{
[...] Кто в резких бороздах чела \\ Отыщет след страстей мятежных? \\ Кто в черноте одежд небрежных \\ Узнает тусклый след крыла? \\ Увы, над гулкой бездной мира \\ Тысячелетия прошли, \\ Изгнанник вольного эфира \\ Стал пленным пасынком земли. [...]
}

[Корвин-Пиотровский 2012, 84]

Skazany na ziemskie życie odczuwa on doczesne pragnienia; mgliste wspomnienie raju, jego blasku i grozy upadku jest mu dostępne jedynie we śnie. Teraz ingeruje swoim słowem w chełpliwe ludzkie polemiki oraz toczy odwieczny i nierozstrzygnięty spór z Bogiem w podrzędnej restauracji. Przedstawiona $\mathrm{w}$ wierszu poetycka wizja ujawnia sprzeczność świata, jego niejednorodność; patos i przyziemność nieustannie przeplatają się ze sobą. Fragmenty tekstu odnoszące się do prawdziwej natury upadłego anioła utrzymane są w stylu wysokim, patetycznym (pytania retoryczne, poetyzmy - np. „страсти мятежные”, „чело”, „бездна мира”), zaś w tych, ukazujących go jako niepozornego, zwyczajnego mieszkańca miasta, autor posługuje się wyrażeniami kolokwialnymi („Когда с работы он идет, // Устало разминая ноги, // Когда у стойки пиво пьет, // Бранит погоду и налоги"; „кабачок убогий”).

Miasto w liryce Korwin-Piotrowskiego to miejsce, gdzie szerzy się niezadowolenie, agresja (Gwiazda wieczorna, Вечерняя звезда, 1929). Bohaterami jego wierszy są włóczędzy (Kiedy reflektor w czarnych przestworzach...), pijani (Brnie przechodzień..., Бредет прохожий спотыкаясь..., 1940), zapuszczony kaleka (Z bramy..., Из подворотенной дырыь.., 1944), wulgarni i ordynarni przechodnie (Styczeń $i$ пос..., Январь и ночь...).

W deskrypcjach miasta poeta obnaża brzydotę, eksponuje takie jego detale jak: kurz (Gwiazda wieczorna; $\mathrm{Na}$ zakurzonym placu parada..., Ha пьильой площади парад..., 1944), brud (Cienie pod mostem), głośne, dysharmonijne i przenikliwe dźwięki - szum, szczęk (Kiedy reflektor w czarnych przestworzach...), skrzypienie (Pudel; Motyle nocne, Ночные бабочки, 1944), krzyk, chichot (Brnie przechodzień...; Styczeń i noc...), odgłosy ambulansu, policyjnych gwizdków (Styczeń i noc...), zawodzenie wiatru ( $W$ dymie chłodnym..., В холодный дылм..., 1929). Dlatego też ceni sobie ciszę, która przynosi ukojenie i pozwala odpocząć (Mgła, Туман). 
Do nieodłącznych atrybutów miejskiej scenerii należą także: mrok, mętne światło słoneczne ( $W$ dymie chłodnym...) lub światło latarni, słabo oświetlające ulice (Deszcz zacina..., Дождь сечет..., 1931), chłód, zamieć, zobrazowana jako gwałtowny żywioł śnieżny ( $W$ dymie chtodnym...) [zob.: Lis-Czapiga 2015], lodowaty wiatr i ulewny deszcz (Motyle nocne; Dziurawy parasol..., Дырявый зонт...), którego szum imituje zastosowana aliteracja (Deszcz zacina...) oraz opustoszałe ulice i zaułki (Biegne przez pustynie zautka..., Бегу пустыней переулка..., Zemsta, Мщение). Pejzaż często spowija mgła, miasto tonie w oparze ( $W$ dymie chłodnym...; Polubiłem Berlin..., Я полюбил Берлин тяжелый..., 1930; Noc cata wiosna paryska..., Всю ночь парижская весна..., 1939; Mgła, Туман; Motyle nocne; Deszcz zacina..., Na ulicy $i$ mrok i mgła...), symbolizującym to, co niepewne, nieokreślone i zagadkowe (Polubitem Berlin...).

Weduty Korwin-Piotrowskiego nierzadko utrzymane są w czarnej i szarej tonacji lub są pozbawione barw ${ }^{4}$ („высь черная” - Kiedy reflektor w czarnych przestworzach...; „В подводный сумрак тень упала”, „блеск черных вод" - Polubitem Berlin...; Idę czarnym nadbrzeżem..., Иду по набережной черной..., 1930; „Сгущая мрак над улочкой старинной, // Бесцветные, как рыбьи пузыри, // Висят [...] фонари" - Dziurawy parasol...; „Дома и улицы черны” - Mgla; „неслышная волна // Как бы подернута золою” - Noc cata wiosna paryska...; „всадник грозный // Сияньем тусклым окружен” - W dymie chtodnym...; „тускнеющая Сена" - Mgta; „Фонтан кирпичный // Мутно газом освещен” - Deszcz zacina...). Poeta wprowadza do opisów również kolor rdzawy („заржавелая канава” - Ide czarnym nadbrzeżem...), wywołujący asocjacje z rozkładem i zniszczeniem [zob.: Lis-Czapiga 2015] (typowymi motywami symbolistów). Wskazana gama kolorystyczna nie tylko służy kreacji miejskiej scenerii, ale jest przede wszystkim metaforą smutku i przygnębienia oraz znakiem obecności w świecie sił tajemniczych. Korwin-Piotrowski sięga także po kontrast - zestawienie dysharmonijnych barw, np. czerni z bielą lub czerwienią wzmacnia siłę ekspresji [Brzoza 1980, 122] ${ }^{5}$, „zmienia optykę widzenia świata [...], akcentuje treści egzystencjalne” [Kotkiewicz 2000, 63] („мостовая [...] черна” - „цосед багровый” - Styczeń i noc...; „высь черная” - „белые отроки”

4 Bliska semantycznie czerni szarość to - jak podkreśla A. Kotkiewicz - ulubiona barwa ekspresjonistów. Jest ona bowiem symbolem spraw wiecznych, metafizycznych, jest kolorem miasta [Kotkiewicz 2000, 63].

5 H. Brzoza pisze: „Ekspresjonistyczna świadomość literacka była - zwłaszcza na terenie Niemiec - często inspirowana przez poetykę i technikę malarstwa, aczkolwiek wizualizacja obrazu poetyckiego stawała się dla niej niekiedy tylko punktem wyjścia" [1980, 123]. 
- Kiedy reflektor w czarnych przestworzach...; „Чернеет линия канала” - „Горят сигнальные огни” - Polubitem Berlin...; „белая арка” - „черные смерчи” - W dymie chtodnym...; „мрак” - „белый сюртук” - „кровь” - Na ulicy i mrok i mgła...). Kolor zatem wartościuje, wyraża doznania, pełni funkcję nastrojotwórczą.

Wiersze poświęcone obrazowi miasta wyrażają tęsknotę Korwin-Piotrowskiego - poety-emigranta za ojczyzną. Kontemplacja berlińskiego pejzażu, z jego mostami i kanałami wywołuje wspomnienie Petersburga i Newy (Polubiłem Berlin...), z kolei bezbarwny, deszczowy Paryż nocą - uczucie smutku oraz nostalgię za Rosją (Dziurawy parasol... $)^{6}$. Dlatego przywołuje on utrwalony w pamięci obraz Północnej stolicy - białe noce, budynek Admiralicji z jego charakterystyczną kopułą i wieżą z iglicą (Zemsta) oraz ojczyzny w ogóle ( $W$ dymie chłodnym...). Bohaterowi jego utworów, mieszkańcowi metropolii, często towarzyszy poczucie osamotnienia i obcości ( $M g l a)$, a zwłaszcza żalu po utraconym kraju, który wzmaga się szczególnie nocą.

Ponure realia miasta, jego brzydotę poeta łączy z tym, co nierealistyczne, nadziemskie i wzniosłe [por.: Kotkiewicz 2000, 39]; jak konstatuje w jednym z utworów:

\section{[...] Мир обычный \\ Чем-то тронут и смущен.}

[Корвин-Пиотровский 2012, 121]

Deszcz zacina...

Podmiot liryczny jest skonstruowany jako świadek i uczestnik niezwykłych zdarzeń - obserwuje tajemnicze zjawy, unoszące się nad ulicą (Moje miasto, Мой город), spadającą gwiazdę, rozświetlającą zamglone miejskie ulice; jego dusza wznosi się ku niebu, łączy się z nim i wyzwala z cielesności (Gwiazda wieczorna).

Przyglądając się sprzedającemu kolorowe baloniki garbusowi ( $Z$ bra$m y . .$.$) , doznaje on fantastycznej wizji - na pustej ulicy z papierosowego$ dymu nieoczekiwanie wyłania się irrealny świat - oto w powietrzu wiruje złota kula, pełna słonecznego światła, powiększa się, upodabnia do planety czy gwiazdy i wznosi się ku błękitnemu nieboskłonowi niczym anioł. Innym razem podmiot liryczny śledzi wirujące nad miejskim ogrodem i szybujące ku górze, ku wieczności baloniki, które po chwili pękają i rozpadają się na

6 Paryż przytłaczał Korwin-Piotrowskiego, na co złożyły się trudne warunki materialne, oschłe przyjęcie w emigracyjnych kręgach literackich, a także poczucie osamotnienia i wyobcowania [Венцлова 2012, 412]. 
strzępki (Niedzielny błękit..., Лазурь воскресная..., 1949). Ów lot nabiera znaczenia symbolicznego, można go odczytać jako przejaw tęsknoty za innym, lepszym bytem.

Miejska rzeczywistość, z jej nerwowym pośpiechem i zgiełkiem jest być może tylko męczącym i krótkotrwałym snem. Przeciwstawiony jest jej obszar niebiański, przepełniony czystością i śpiewem chórów anielskich. Podmiot liryczny nie tylko dostrzega jego odbicie w tafli rzeki (swoistym zwierciadle) za sprawą napotkanego anioła, ale także doświadcza - sam bowiem staje się posłańcem i sługą Boga i dołącza do anielskich zastępów (Kiedy reflektor w czarnych przestworzach...).

Kontemplacja przepełnionego blaskiem nocnego nieboskłonu rodzi pragnienie, aby wzlecieć ponad posępną i przygnębiającą miejską codzienność, pokonać ziemskie ograniczenia (Brnie przechodzień...). Niekiedy bohaterowie utworów Korwin-Piotrowskiego posiadają zdolność swobodnego unoszenia się nad ziemią i odbywają lot w przestrzeni powietrznej. Na przykład posiwiały, niedoceniony poeta z wiersza Fregata (Фpezam, 1944), który wzlatuje niczym ptak nad miejskim placem targowym, z jego pstrokacizną, gwarem, wrzawą i nieskrępowanym pospólstwem lub podmiot liryczny w utworze $Z$ a drzwiami głos wibruje... (За дверью голос дребезжит..., 1944), szybujący nad miastem, więzieniem i na podobieństwo gwiazdy wzlatujący w lśniące obłoki. Innym razem odczuwa on wewnętrzne rozdwojenie, ma świadomość przywiązania do dolnego świata; jego dusza pozbawiona możliwości lotu rejestruje jedynie sygnały obecność innych wymiarów (Deszcz zacina...).

Dysharmonię pomiędzy realnością i tym, co irrealne, podkreśla także kolorystyka. W przedstawieniu zdarzeń nadprzyrodzonych, w deskrypcji sfery niebiańskiej (w odróżnieniu od przestrzeni miejskiej) poeta stosuje barwy, konotujące wartości pozytywne - białą, srebrną, lazurową, niebieską, złotą (Gwiazda wieczorna; Kiedy reflektor w czarnych przestworzach...; Z bramy..., Moje miasto) lub określenia, sugerujące ich mnogość i różnorodność ( „пестрая волна [детских шаров]" - Z bramy... $)^{7}$.

Omówiona tematyka bez wątpienia zajmuje szczególne miejsce w liryce autora Latawca. Obraz miasta ukazanego w przeanalizowanych wierszach ma

7 Świadomość zawieszenia jednostki pomiędzy ostro kontrastującymi ze sobą codzienną rzeczywistością i rzeczywistością duchową, wiecznością, pomiędzy bytem i niebytem, wkroczenie cudu w powszedniość życia zbliżają lirykę Korwin-Piotrowskiego z poezją Chodasiewicza (co jest szczególnie widoczne, np w utworach Brnie przechodzień..., Fregata), którego twórczość znał i cenił [Венцлова 2012, 410, 417]. Jak zauważa Jurij Terapiano, Korwin-Piotrowski w swoich utworach (w obrazach poetyckich, tonacji) był niekiedy bliski Chodasiewiczowi, nie podzielał jednak jego sceptycyzmu [Терапиано 1987, 238]. 
wydźwięk negatywny. Korwin-Piotrowski, sam będący mieszkańcem wielkich metropolii - Berlina, Paryża i Los Angeles, ilustruje konkretne zjawiska miejskiego życia, wydobywa detale urbanistycznego pejzażu, rejestruje dźwięk (przenikliwy, ostry) oraz barwy (gama kolorystyczna jest wyraźnie ograniczona, z przewaga szarości i czerni). W swoich utworach poeta stawia podmiot liryczny na pograniczu świata rzeczywistego i fantasmagorycznego, niską miejską rzeczywistość przeciwstawia sferze niebiańskiej, odczuwa wewnętrzne rozdwojenie. W poetyckich wizjach Korwin-Piotrowski odwołuje się do tradycyjnej symboliki (mgła, lustro, czerń, lot), do tradycji literackiej, łącząc je z realiami współczesnymi, nawiązuje do estetyki symbolistów rosyjskich, sięga też do poetyki ekspresjonizmu, co przejawia się $\mathrm{w}$ ujemnej waloryzacji metropolii, a co za tym idzie, w eksponowaniu takich zjawisk jak: brud, podejrzane miejsca, środowisko przestępcze, wulgarność mieszkańców, elementy akustyczne - nieprzyjemne, głośne dźwięki, mglistość oraz ciemność, rozświetlona nikłym światłem latarni, amorficzne postaci, wykorzystanie kategorii cienia, szara i czarna tonacja kolorystyczna budująca nastrój, odzwierciedlająca emocje, kontrasty (czerń-biel), jak również poczucie binarności świata, alienacji, groteska ekspresjonistyczna zacieranie granic pomiędzy rzeczywistością i fantastyką, obecność w świecie elementu demonicznego, brzydota, kalectwo, związek ze światem wizji, urojeń, zespolenie elementów niejednorodnych, wzajemnie wykluczających się, np. poetyzmów i prozaizmów. Wszystko to składa się na sugestywny wizerunek miasta, przestrzeni obcej, ponurej, wywołującej smutek, poczucie zagubienia oraz tęsknotę za krajem ojczystym.

\section{Literatura}

Biedermann H., 2003, Leksykon symboli, przekł. J. Rubinowicz, Warszawa.

Brzoza H., 1980, Z problemów estetyki ekspresjonizmu, [w:] Poręba S. (red.), 1980, Zagadnienia pradów i kierunków w literaturze rosyjskiej, Katowice, s. $120-136$.

Kasack W., 1996, Leksykon literatury rosyjskiej XX wieku, Wrocław.

Kodzis B., Wieczorek A. (red.), 1994, Muza na wygnaniu. Rosyjska poezja emigracyjna. Antologia t. 1 (1920-1940), Opole.

Kotkiewicz A., 2000, Z dziejów ekspresjonizmu rosyjskiego. Opowiadania Leonida Andriejewa, Kraków.

Lis-Czapiga A., 2015, Pejzaż w liryce Wtadimira Korwin-Piotrowskiego (wybrane aspekty), [w:] Kodzis B., Giej M. (red.), 2015, Stowianie na emigracji. Literatura - Kultura - Język, Opole - Racibórz, s. 333-342. 
Nawrocki W., 1987, Ekspresjonizm: teorie programowe i praktyka literacka, „Kultura" nr 44 (127), s. 7-10.

Paszkiewicz A., 1999, Z problematyki ekspresjonizmu w literaturze rosyjskiej. Od Leonida Andriejewa do Wsiewołoda Wiszniewskiego, Wrocław.

Ratajczak W., 2006, Stownik motywów literackich, Poznań.

Венцлова Т., 2012, О жизни и творчестве Владимира Корвин-Пиотровского, [w:] Корвин-Пиотровский В., 2012, Поздний гость. Стихотворения и поэмы, Москва.

Иванова С.А. (ред.), 1998, Русская Атлантида. Поэзия русской эмиграции. Младшее поколение первой волны, Москва.

Каннак Е., 2003, Берлинский кружок поэтов (1928-1933), [w:] Сорокина В.В. (ред.), 2003, Русский Берлин, Москва, s. 279-282.

Корвин-Пиотровский В., 2012, Поздний гость. Стихотворения и поэмь, Москва.

Крейд В. (ред.), 1999, Словарь поэтов Русского Зарубежья, Санкт-Перербург.

Скатов Н.Н. (ред.), 1998, Русские писатели ХХ века. Биобиблиографический словарь, ч. 1. А-Л, Москва.

Струве Г., 1996, Русская литература в изгнании: Опьт исторического обзора зарубежной литературь, Париж - Москва.

Терапиано Ю., 1987, Литературная жизнь русского Парижа за полвека (1924-1974). Эссе, воспоминания, статьи, Paris - New York.

\title{
THE PICTURE OF A CITY IN VLADIMIR KORVIN-PIOTROVSKIYI'S POETRY
}

\author{
S U M M A R Y
}

Vladimir Korvin-Piotrovskiyi (1891-1966) is recognised as a representative of the First Wave of Russian Emigration.

Poems devoted to the metropolis theme deserve special attention among all of his works. This motif plays vague role in the author's creative activity and frequently becomes the leading idea of his poems. Undoubtedly, the influence of Russian poetry and German expressionism can be traced in Korvin-Piotrovskiyi's lines devoted to the picture of a city.

Metropolis is depicted in negative way in the author's works under investigation. Korvin-Piotrovskiyi presents specific phenomena from the city life, underlines details of urban landscape, records the sound (penetrating, hard, unpleasant) and colours (especially grey and black), shows suspicious places, criminal circles. The poet leaves his lyrical subject on the borderline between the real and fantastic worlds. In his poetic visions Korvin-Piotrovskiyi appeals to the traditional symbolism (mist, mirror, black, flight), to the literary tradition, links them with contemporary realities. 